\title{
Evaluation and Prioritization of Internet Banking Service Quality: The Case of Egypt
}

\author{
Miran Ismail Hussien ${ }^{1}$, Rasha Abd El Aziz² \\ Cardiff Metropolitan University, Wales, UK \\ miranismailecommerce@gmail.com
}

Arab Academy for Science and Technology, Jamal Abd El Nasser, Miami, Alexandria, Egypt

rashaayo@gmail.com

\begin{abstract}
Changes in technology made a paradigm shift in the banking industry. Technology itself created its world in the globe of human beings. Internet banking is a service that allows customers to perform a wide range of financial services through a bank's website. With the rapid diffusion of the Internet, web-based banking has become an alternative channel to provide banking services and products. Due to the deepness of technology in the service sector, there is a shift from the traditional service quality to electronic service quality (ESQ) in order to fit the Internet banking strategy. The aim of the paper is to rank and prioritize the Internet Banking Service Quality dimensions according to customer's relevant importance from both bank sectors namely, private and public banks using Analytic Hierarchy Process (AHP) model, which is a structured technique for organizing and analyzing complex decisions. AHP has been seen as a high potential decision support tool in banking industry.
\end{abstract}

\section{Keywords}

Internet Banking, Service Quality, Analytic Hierarchy Process (AHP).

\section{Academic Discipline And Sub-Disciplines}

E-Commerce; Survey Studies;

\section{SUBJECT CLASSIFICATION}

E-Service Quality

\section{TYPE (METHOD/APPROACH)}

Survey; Literary Analysis; Analytic Hierarchy Process

\section{Council for Innovative Research}

Peer Review Research Publishing System

\section{Journal: International Journal of Management \& Information Technology}

Vol. 8, No. 3

editor@cirworld.com

www.cirworld.com, member.cirworld.com 


\section{INTRODUCTION}

The incredible growth of the Internet has certainly changed the landscape of service industry by transforming the ways on how consumers interact with the firm and how the firm especially in the banking industry is delivering the service. Thus, the Internet is considered a powerful tool for the bank strategic plan to increase the overall banking service offerings and to create higher standard. Consequently, banks need to focus on the key elements of an effective Internet strategy, which are the quality of services to provide customer satisfaction and retention [1] [2] [3].

Recently, many banks use the Internet as new market delivery channel to offer their customers many service 24 hours with no human interaction between the customers and bank information system. Also, previous studies find that the bank e-service quality plays a very important role in customer's perception of overall banking service quality [4]. Also, banks have been moving towards the Internet Banking (IB) currently offering customers online access to their accounts. In fact, major banks have offered a variety of services, such as checking account balance, paying credit cards and Funds transfer. Although banks have focused their attention on improving their banking service quality, many of them still seem to be lagging behind their customers' ever increasing demands and expectations [5] [6].

Service quality has been recognized as a key strategic issue for organizations operating in service sectors [7]. Service quality has become an increasingly important factor for success and survival in the banking industry. Due to the deepness of technology in the service sector, there is a shift from the traditional service quality to electronic service quality (ESQ) in order to fit the Internet banking strategy [8] [9]. Thus, the quality of Internet banking services has become a major area due to its strong impact on business performance, lower costs, customer satisfaction and loyalty. Therefore, the purpose of this study is to rank and prioritize the Internet Banking Service Quality dimensions (IBSQ) according to customer's relevant importance from both types of banks namely private and public banks in Egypt using Analytical Hierarchy Process (AHP) technique.

\section{LITERATURE REVIEW}

\section{Internet Banking}

Internet Banking (IB) is one of the best alternatives for traditional banking [10]. It has become the self-service delivery channel that allows banks to provide information and offer services to their customers with more convenience via the web services technology [88]. It is one of the most important factors in the business economy today also especially as it is considered a lower-cost delivery channel and a way to increase sales [11].

According to annual surveys of the American Banks Association (ABA), Internet banking has become the most preferred choice of banking for the most bank customers. The ABA Survey released on 9 October 2012 shows that $39 \%$ of bank customers interviewed prefer Internet banking the most, while only $6 \%$ prefer mobile banking. Even for the most conservative group of customers who are above the age of 55, Internet banking has become the first choice of banking since 2011 according to the ABA Surveys 2011 and 2012. Although ABA surveys focus on American banking sector only, a similar pattern of the increased use of Internet banking has been observed in other countries [12].

Thus, IB contributes to increasing the efficiency of the banking operation as well providing more convenience to customers [13]. Recently, more and more traditional brick and mortar banks has been moving to the Internet which is a new fastest, easiest, advanced, highly informative and modernized way of banking, namely Internet banking services, in order to sustain their competitiveness in the market place [14] [15] and in order to keep up with the high customer expectations [16][17]; for to them, IB is more convenient and flexibility compared with retail banking [18] [19].

It is important for the banks to know the factors that influence the customer adoption of IB through focusing on improving their banking service quality [17]. Service Quality is an important element of value and is a key strategic asset of companies for applying on the market regardless of whether it is a product or a service that enable organizations to distinguish themselves from other competitors [20] [21]. However, many banks still lag behind their customer's ever-increasing demands and expectations [14] [22 [21], despite the fact that, customer satisfaction has always been regarded as a key success factor of organizations [23] [24] [22].

\section{Internet Banking Service Quality}

Service quality is a key determinant in differentiating service offers and building competitive advantages, since the costs of comparing alternatives are relatively low in online environments $[25,26]$. Hence, service quality is a crucial issue in the Internet banking. However, service quality has been considered a problem e-service quality evaluation because e-service is different from traditional service with three aspects standing out: the absence of human interaction, the absence of traditional tangible dimension, and self-service of customers [27] [28] [29]. In this light, service quality is not appropriate for measuring e-service quality. Accordingly, this creates a special interest in measuring and monitoring service quality in the virtual world and in the investigation of the e-service definition and dimensions [30] [31], as some of the important factors that influence customers of the e-commerce web sites in order to develop an instrument for measuring e-service quality [32].

As a result [33] believes that how the service is delivered to the customers and how company's websites perform is a sense of loyalty that comes from good services offered by companies. Customers evaluate both what the company offers and how it offers it; because of the lack of face-to-face interaction with service representatives, the user 
interface (site design) is what customers of e-services interact with, and as such it can be expected to influence their evaluation of the overall service quality [34] [35]. That is why it is advisable that companies very well consider the design and function of their websites, because customers might get frustrated and eventually be discouraged to visit the website if it cannot be accessed easily or the work with it is very slow. Additionally, the information content of the website is considered important for online evaluations [25]. Thus e-service quality is the key success for any e-tailer doing business in the competitive global e-commerce environment, building customer loyalty and satisfaction [5] [36].

\section{Internet Banking Service Quality Dimensions}

With the increase of e-service adoption in business field, much of the studies in e-service quality take a combination of traditional service quality dimensions and web interface quality dimensions as the starting point. In 1996, [37] has studied the measures of e-service quality focusing on web site design, and argued that there are 6 basic parameters in the judgment of e-service quality: website design, reliability, and delivery, ease of use, enjoyment and control. In 1999, [16] investigated the influence of technology such as ATM, telephone, and Internet on the delivery of banking service. Their study identified another 6 underlying dimensions of electronic banking service quality: Convenience/accuracy, feedback/complaint management, efficiency, queue management, accessibility, and customization.

Later in 2000, [38] have identified another four dimensions close to those identified by Dabholkar, information quality, system use, system design quality and playfulness. Another set of dimensions was identified by [39] as the most important service quality dimensions for both companies and their customers. These dimensions are trust; inter activeness, ease of use, content/ functionality of websites, reliability and speed of delivery. Moreover, [40] suggest that five service quality dimensions identified by [41] can be applied in e-commerce by switching tangibility with the user interface, since it describes how the service is offered to the customers. Responsiveness could refer to the speed of company's response to the customers. Reliability could relate to timely delivery of ordered goods, accurate information and correct links. Assurance could be interpreted as the safety of online transactions and the policy for using personal information by the company, while empathy could refer to the degree of customization of communications based on customers' personal needs.

Attempts to develop specific measuring instruments for service quality in e-commerce initially focused on the technical dimensions of e-service quality such as website design, navigation, speed, and content [14]. However, [42] suggested that a more integrated vision of e-service quality was required based on the criteria that are used by online customers to evaluate the holistic service including both the transaction and the post-transaction experience. Also, [43] have also studied online service quality and in an attempt to better understand customers and provide services that meet their needs, they have proposed 15 different dimensions: performance, features, aesthetics, reliability, structure, storage capacity, service ability, security and system integrity, trust, product/service differentiation and customization, responsiveness, web store policies, reputation, assurance and empathy. Furthermore, [42] stated that the SERVQUAL scales by [44] cannot be applied as such to e-services but additional dimensions may be needed to fully capture the construct of e-service quality. Thus [40] and [42] emphasize that e-service quality dimensions can be added and/ or eliminated as needed. In 2006, [45] have extended Parasuraman's dimensions into a 9 dimensions scale in e-service quality to evaluate the service quality of websites in the apparel-retailing sector.

With the rapid diffusion of the technology, e-banking and Internet banking (IB) in particular has become an alternative channel to provide banking services and products through a secured website. There are several studies conducted to analyse the perceptions of IB users on dimensions. [46] has stated that the quality of information, ease of ordering and reliability are significant in IB than security aspect. [47] argued that the IB might lead to strong relationships with customers because customer expectations have a tendency to change over time. Another study undertaken by [48] on the key determinants of IB service quality concludes that a total of 17 dimensions were identified classified into 3 categories of IB service quality: Customer service quality, Online systems quality and Banking service product quality. Other factors affecting consumer acceptance and adoption of IB have been investigated in many countries such as the US [49] [50] [51] [52] [53]. In 2010, a study by [14] found five dimensions and 17 items in the measurement scale for measuring the service quality of IB. The five dimensions are named customer service, web design, assurance, preferential treatment, and information provision.

Similarly, [54] evaluate the relationship between Internet service banking quality and customer satisfaction at the bank. The study found that more customers were satisfied the entire IBSQ dimension items while customer satisfaction was highest for the assurance dimension. The least satisfied quality item was in customer service and the Internet banking system's ability to guide customer to resolve problems. The banks management need to keep improving the web design of the internet banking portal to make it more navigable, provide sufficient information and make it easier for customers to complete online transactions. For instance, Internet banking is increasing rapidly so it is important for the banks to know the preferences of the customers. Also, [17] find out the effects of eight dimensions (web design, security, trust, product diversification, credibility, collaboration, access and communication) on the service quality perception of Internet banking. Trustworthy and secured online system would make the decision easy for the customer moving to Internet banking. Also, it is very important that their transactions and personal information must be fully secured. In case of any query there must not be communication gap and customer has access to the management and banking staff when needed. Thus, banks works on these determinants that it would surely increase its customers using Internet banking.

Accordingly, Internet banking has become a way by which banks could deliver superior service quality as a competitive tool against industry rivals [55] and improvement in the Internet service quality could be made if 
customers' satisfaction and perception of it can be measured in the first place. Effective measurement of customer satisfaction for various dimensions of Internet service quality could be very useful in the allocation of resources and in the segmentation of customers [56].

\section{Internet Banking Service Quality in Developing Countries}

In Developing countries, the findings of the study titled "Internet Banking Acceptance in the Context of Developing Countries: An Extension of the Technology Acceptance Model" by [57] indicate that the security, quality of the Internet connection and awareness about Internet banking and its benefits have significant effects on the perceived usefulness (PU) and perceived ease of use (PEOU) of Internet banking acceptance. Also, it was revealed that the effects of education and trust have significant impact on the attitude towards the acceptance Internet banking. Another study by [58] stated that the overall respondents' perception on Internet Banking service quality was a satisfactory. The Internet Banking service quality perceptions are not influenced by whom the service provider is, age or gender. Respondents' perceptions were neutral or indifferent on the responsiveness service quality dimension. Lastly there were five dimensions that the respondents evaluated Internet Banking service quality on, that of efficiency, performance, security, responsiveness and contact.

Moreover, [59] performed an analysis on the Internet banking and the satisfaction level of customers in Bangladesh. It has been observed through the outcomes of the research that a relationship exists between the Internet banking services and customer satisfaction level. The main dimensions examined are reliability, empathy, responsiveness and assurance which results in adequately satisfying the customers, It has been recommended that internet banking system should be made more formative and the government of Bangladesh should play a leading role in fostering the framework of Information Technology in Bangladesh.

Another paper by [60] analyses the impact of Internet banking service quality dimensions on the Overall Internet Banking Service Quality and customer satisfaction in India. The results of exploratory factor analysis (EFA) revealed five dimensions (Security/Privacy, Reliability, Efficiency, Responsiveness, and Site Aesthetics). This five dimensional model arrived through EFA was validated through a confirmatory factor analysis (CFA). The proposed research model shows acceptable fit indices. Impact of these dimensions on the Overall Internet Banking Service Quality and customer satisfaction are analysed using multiple regression technique. Findings indicate that all dimensions carry significant impact on the Overall Internet Banking Service Quality perceptions and customer satisfaction. However, Security/Privacy and Efficiency dimensions carry the maximum impact on the Overall Internet Banking Service Quality and satisfaction respectively.

Another study in Pakistan by [61] this study determines the effects of Internet banking service quality dimensions on customer satisfaction by using SERVQUAL model. The results indicate significant positive relationship between assurance, tangibility, reliability and responsiveness with customer satisfaction. Conversely, empathy shows positive but insignificant effect on customer satisfaction. It is recommended that the management of online banks have to focus on making the design and content of the websites more visually appealing to grab the attention of existing customers, as well as to attract new customers.

Finally, the key to getting more customers for the banks through the online service is not the attraction of the Internet itself but the service quality offered to the customers. This argument was supported by [62], who found that 87 per cent of Internet banking customers want to make a variety of financial transactions at one site (so called "one-stop shopping").

\section{Internet Banking Service Quality Dimensions Summary}

After reviewing the literature related to Internet Banking service quality, a number of research questions can be raised. Which factors contributes more towards satisfaction of customers in banking system. Also, it has been found that much of the service quality research literature has focused more on service quality dimensions and its adoption based on the basic definitions. Not too many references have been found about the application of underlying theories and the reason for their choice of their service quality attributes. Thus, an exerted considerable effort in filling this gap of research literature base by developing the a previous study by the paper's author on service quality domain by explaining the rational approach in identifying the dimensions and items of web-based service quality based on the evaluation of the criteria [62]. The current research extends the work by weighting the dimensions to set the ranking and the importance of each dimension in Internet Banking environment. The previously determined e-service quality attributes are as follows [62]:

1. Usability reflects the ease of navigation in which the site contains functions that help customers find what they need and allows them to move easily and quickly through the pages.

2. Reliability refers to the ability to perform the promised service reliably and accurately.

3. Responsiveness refers to the willingness to help customers and provide prompt service.

4. Privacy refers to degree to which customers believe the site is safe from intrusion and personal information is protected.

5. Incentive indicates encouraging consumers to browse and use the website by rewarding them. 
6. Fulfillment includes accuracy of service promises, having products in stock and delivering the product within the promised time.

7. Efficiency refers to the ability of the customer to get to the website, find their desired product and information associated with it and to check it out with minimal effort.

8. Assurance refers to the knowledge and courtesy of employees and their ability to inspire customers' trust and confidence.

9. Empathy refers to the caring and individualized attention the firm provides to its customers.

Egyptian Banks

In Egypt, banks can be classified as public sector, private \& joint venture, or foreign according to ownership. All specialized banks are state owned and are assigned the task of providing long term finance for real estate, agricultural and industrial development. They mainly cater to the needs of the private sector and depend in their fund raising on borrowing from financial institutions [63]

There are currently 39 banks in Egypt, 5 public and 34 private banks. The five public sector banks are the largest operating banks in terms of balance-sheet size, accounting for nearly $50 \%$ of total bank assets. They have a significant market share in retail and corporate banking services through large branch networks and close relationship with state-owned companies [64].

Based on Central Bank of Egypt in 2009, 19 out of 39 banks (58\%) were offering Internet banking services [65]. However, Internet banking services have not taken off in Egypt because of low rates Internet penetration. Based on the Ministry of Communication and Information Technology (MCIT), the number of Internet users in Egypt is 32.49 million [66]. Both the website of the Central Bank of Egypt and Directory of Egypt's Banks guided the research in locating private banks showed that only $36 \%$ had Internet Banking systems installed and $22 \%$ for public banks [67].

\section{RESEARCH DESIGN}

This paper aims to utilize IBSQ criteria for evaluating and ranking e-service quality dimensions for public and private for the Egyptian bank context through designing a structured questionnaire see in appendix. Although, AHP is widely used as decision support tool in business and industry, this current study have focused on financial sector of service industry, which is banks and financial institutions; are key decision makers for controlling application of finance, and availability in the market. AHP application in banking sector is growing; it is being combined with conventional bank evaluation or credit rating tools. With the global financial crisis, utility of AHP is being perceived higher in banking application [68].

It will be analyzed using analytical tool called Analytic Hierarchy Process (AHP). AHP is a structured technique for organizing and analyzing complex decisions [69]. It was developed by Saaty in the 1970s [70] [71] and has been extensively studied and refined. He explained AHP as a theory of measurement that depends on experts' judgments using pairwise comparisons in order to derive priority scales [70]. It is considered an excellent multi criteria decisionmaking tool due to its simplicity compared to the previous decision support methods. It also enables qualitative and quantitative into the same decision making methodology by giving a basis for eliciting, discussing, recording, and evaluating the elements of a decision [1]. It uses a process of pairwise comparisons to determine the relative importance and the priority of alternatives in a multi-criteria decision-making problem (MCDM) by [72] and [68, 73]. Similarly, AHP involves decomposing a complex and unstructured problem into a set of variables that are organized into a hierarchy [74] [75]. It enables decision-makers to make choices among a number of alternatives and criteria by formulating priorities and making a series of tradeoffs [72].

AHP structure is translated into a series of general questions, such as 'How important is criterion A relative to criterion B?' The input to AHP models is the decision maker's answer to a series of questions and is then termed pairwise comparisons. Questions of this type may be used to establish both weights for criteria and performance scores for options on the different criteria. It is assumed that a set of criteria has already been established based on AHP model. For each pair of criteria, the decision-maker is then required to respond to a pairwise comparison question asking the relative importance of the two [76]. AHP responses are gathered in verbal form and subsequently codified on a ninepoint intensity scale [68] [77]. Also, [78] determine the most accurate guidelines for assessing the pairs can be found in Table 1. In every pair we assign the degree of dominance of one element over another. The exceptional supremacy of one criterion over another can be assessed at 9 , equality at 1 . If the second criterion is more important than the first one record the reciprocal value. Thus we obtain the values in the region from 1/9 to 9 . This model of assessment of ratios is empirically confirmed as accurate enough for the majority of problems. To reach the final assessment employs the procedure of weighted average. This can be obtained by multiplying importance of criteria and level of certainty. The values in between such as $2,4,6,8$ are intermediate values that can be used to represent shades of judgment. The scale measurement from 1 to 9 in a fundamental scale of measurement listed in Table 1.

Table 1. Pair-wise comparison scale for AHP preference $(79 ; 70)$

\begin{tabular}{|c|l|l|}
\hline $\begin{array}{c}\text { Preference on pair wise } \\
\text { comparison }\end{array}$ & $\begin{array}{l}\text { Preference } \\
\text { Number }\end{array}$ & Explanation \\
\hline
\end{tabular}




\begin{tabular}{|c|c|c|}
\hline Equally important & 1 & $\begin{array}{l}\text { Two activities contribute equally } \\
\text { to the objective. }\end{array}$ \\
\hline $\begin{array}{l}\text { Weakly importance of one } \\
\text { over another }\end{array}$ & 3 & $\begin{array}{l}\text { Experience and judgment } \\
\text { slightly favor one activity over } \\
\text { another. }\end{array}$ \\
\hline $\begin{array}{l}\text { Essential or Strongly } \\
\text { important }\end{array}$ & 5 & $\begin{array}{l}\text { Experience and judgment } \\
\text { strongly favor one activity over } \\
\text { another. }\end{array}$ \\
\hline $\begin{array}{l}\text { Demonstrated important } \\
\text { or Very strongly important }\end{array}$ & 7 & $\begin{array}{l}\text { An activity is strongly favored } \\
\text { and its dominance is } \\
\text { demonstrated in practice. }\end{array}$ \\
\hline $\begin{array}{l}\text { Absolute importance or } \\
\text { Extremely important }\end{array}$ & 9 & $\begin{array}{l}\text { The evidence favoring one } \\
\text { activity over another is the } \\
\text { highest possible order of } \\
\text { affirmation. }\end{array}$ \\
\hline $\begin{array}{l}\text { Intermediate values between } \\
\text { the two adjacent judgments }\end{array}$ & $2,4,6,8$ & When compromise is needed. \\
\hline
\end{tabular}

\section{Data Collection}

The data collected from the survey is being utilized, as these customers were familiar with the practices in their banks, they served as the evaluators to determine the relative weights against a given list of critical factors and sub-factors affecting the level of service quality. The AHP questionnaire is administered in person in Alexandria in Egypt and electronically in order to increase the diversity of respondents, increase the number of returned questionnaires, and increase the geographical accessibility. It consists of 3 parts, concerning the first and third parts are simple and easy to fill some general and demographic questions to be filled however the customers had certain difficulty with the second part in the questionnaire to rank the dimensions and prioritizing 9 pairwise comparisons to be made, although the customers tried hard and filled all the spaces in the pairwise comparison matrices. According to all literature surveys, the dimensions of the study for evaluating Internet banking service quality are determined as Usability, Reliability, Responsiveness, Privacy, Incentive, Fulfillment, Efficiency, assurance and empathy.

The study uses AHP to conduct the decision analysis to show how Internet banking users in Egypt rank the dimensions based on their level of importance, its process comprises to the following main steps [80]. The main tool used for data analysis was Microsoft Excel, since performing the calculations on spreadsheets would facilitate any statistical tests and also comparative analyses between different spreadsheets. The study has gone through AHP steps; the first step is to structure the hierarchy of the framework to represent the problem. The second one is to establish Pair-wise Comparison Matrix based on a scale of 1 to 9 as per the definition of weights then calculating the consistency of each questionnaire followed by calculating the priority vector to set the ranking of each dimension, and calculated the geometric mean for each dimension. Finally, determine their weights and synthesis to obtain the weights for the criteria.

\section{Sample Size}

The sampling used in this study is stratified random technique; because it attempts to restrict the possible samples to those which are "less extreme" by ensuring that all parts of the population are represented in the sample in order to increase the efficiency that is to decrease the error in the estimation. In stratified sampling the population of $(\mathrm{N})$ units is first divided into disjoint groups of $\mathrm{N} 1, \mathrm{~N} 2, \ldots, \mathrm{Nh}, . . \mathrm{NL}$, units, respectively. These subgroups, called strata, together they compromise the whole population, so that $\mathrm{N} 1+\mathrm{N} 2+\ldots \mathrm{NL}=\mathrm{N}$ From each stratum a sample, of pre-specified size, is drawn independently in different strata. Then the collection of these samples constitutes a stratified sample. If a simple random sample selection scheme is used in each stratum then the corresponding sample is called a stratified random sample [81]. 500 questionnaires were distributed over the targeted bank customers from Alexandria in Egypt. Yet only 100 completed questionnaires were returned.

AHP is a subjective method that is not necessary to involve a large sample, and it is useful for research focusing on a specific issue where a large sample is not mandatory [82] [83] [84]. Therefore, the calculation of inconsistency ratio is vital to measure how consistent the judgments have been relative to large samples. Based on [85] [86], Consistency Ratio (CR) and the criteria weights obtained by both of them. Accepting/rejecting consistency in the analytic hierarchy process (AHP) according to saaty's approach was depending on apportionment Consistency Index (Cl) and Random Consistency Index $(\mathrm{RCI}) \leq 0.1$ consistency ratio $(\mathrm{CR})$. If the value of $\mathrm{CR}$ is 0.1 or less, then the pair-wise reciprocal comparison matrix is considered to be consistent and acceptable. 
In the current study, the number of consistent questionnaires was 67 questionnaires out of 100 questionnaires because one of the main difficulties of AHP approach is that it needs more experienced personnel to carefully select and structure the analytic hierarchy tree and to make pair-wise comparisons with consideration of offsetting effects among criteria and sub-criteria. Another challenge of AHP approach is that it can only take into consideration a limited number of factors, either regarding selection criteria or the number of potential suppliers. Too many factors will make pair-wise comparison difficult and time taking [87]. All the population of the study has already bank account and used the Internet banking services from which $100 \%$ of the sample used Internet banking service.

\section{DATA ANALYSIS}

Questionnaire general questions were statistically calculated and simple frequencies were derived, and are reported below:

- $50.7 \%$ agreed with IBSQ, $25.4 \%$ were strongly agree with IBSQ offered by the bank followed by $22.4 \%$ were neutral.

- $47.8 \%$ are males while $52.2 \%$ are females.

- $10.4 \%$ were less than 25 years old, $62.7 \%$ from 25 to less than $40.17 .9 \%$ between 40 to less than 60 , and $9 \% 60$ or over.

- $4.5 \%$ have between L.E. 500 and LE. 2000, 32.8\% have between L.E. 2000 and 5000, and 49.3\% have between L.E. 5000 and 15000 , and $13.4 \%$ have more than 15000 or more.

- $56.7 \%$ were postgraduates, $41.8 \%$ had graduated, and $1.5 \%$ was no qualification.

- $70.1 \%$ were salaried employee, $17.9 \%$ business man, $1.5 \%$ were student, $1.5 \%$ were unemployed, and $9 \%$ were retired.

\section{AHP Technique}

The following section demonstrates how customers evaluate the Internet banking. This study formulated the AHP decision hierarchy for evaluating IBSQ. The attainment of criteria is vital for satisfying the overall objective. The dimensions in this study include Usability, Reliability, Responsiveness, Privacy, Incentives, Fulfillment, Efficiency, Assurance and empathy. Then, the pair-wise comparison matrix of the nine criteria to the overall target of ESQ was established. Table 2 shows the overall weights for criteria.

Table 2: Comparisons Matrices for Dimensions

\begin{tabular}{|c|c|c|}
\hline \multicolumn{2}{|c|}{ Table 2: Comparisons Matrices for Dimensions } \\
\hline Dimensions & Weights & 1 \\
\hline Privacy & 0.238 & 2 \\
\hline Reliability & 0.162 & 3 \\
\hline Responsiveness & 0.145 & 4 \\
\hline Efficiency & 0.120 & 5 \\
\hline Fulfillment & 0.110 & 7 \\
\hline Incentives & 0.082 & 8 \\
\hline Usability & 0.049 & 9 \\
\hline Empathy & 0.049 & 0.045 \\
\hline
\end{tabular}

The above table explores practically the ideas presented in this paper. The results shown indicate that 'Privacy' out of the nine service quality dimensions is considered as the most important; it entails the protection and appropriate use of the personal information of customers, this is logic as the bank handles some confidential and personal information followed by the 'Assurance' to be very strongly important dimension this would suggest that efforts to improve the quality of interactions between a customer and a service provider are likely to have an important and positive effect on customer satisfaction also to gain trust of their customers and building good name and reputation. 'Reliability' is come in the third level of importance as customers found their information is accurate and available. 'Responsiveness' is ranked to be the fourth one; this can be explained by the fact that this dimension is mainly related to cases when the customers had some problems with the online services provided by the bank and many people seem not to have encountered such problems. 'Efficiency' is the fifth place in the rating of the service quality dimension then 'Fulfillment' comes in the sixth level followed by 'Incentives' weighted in the seventh level, which reflects that customers do not care about encouragement; they care more about the Internet banking services. Finally 'Usability' and 'Empathy' are 
the two least dimensions because the bank customers recognize that these two dimensions are not essential for the Internet Banking. They are being more satisfied when most of the services are working well. In addition, they thought that the last three dimensions will be better ranked if they evaluated a shopping website.

\section{CONCLUSION}

Analytic Hierarchy Process can be used to help decision makers in banking sector. The nature of banking services encourages customers to demand the highest possible quality. In order to achieve this, it is essential to be very close to customers to capture information on customer current and future needs, expectations and perceptions. The main objective of this study was to rank and prioritise the Internet banking service quality through designing and analyzing Analytic Hierarchy process Questionnaire.

This study justifies that the application of AHP method in service quality dimensions is reasonable and it provides a robust and encompassing treatment for decision makers in both qualitative and quantitative ways. The significant difference between the present study and the previous studies is that it adds more value on the study of Internet banking prioritization and level of importance of the criteria based on their weights of each criterion.

This paper has suggested that using AHP model will perform marvelously in evaluating Internet banking service quality dimensions. The AHP methodology is used to assign relative importance of feature weighting for the nine criteria. This methodology is an effective means for weight extraction from multiple expert judgments. From customer perspective, the top priority is privacy aspect then followed by Assurance, Reliability, Responsiveness, Efficiency, Fulfillment, Incentives, Usability and Empathy respectively.

In Future Research, more general customers should be interviewed for obtaining a generalization result. Also, this idea can be applied in other countries and the differences in the priority sets can constitute a basis for concluding the cultural effects. Although the findings of this study can provide insight and understanding for banking website managers to develop customized websites that cater much better to the needs of today's sophisticated customers, some interesting points may be worth investigation for further researches.

\section{REFERENCES}

[1] Syamsuddin, I., \& Hwang, J. 2009. The application of AHP model to guide decision makers: a case study of e-banking security. In Computer Sciences and Convergence Information Technology, 2009, November. ICCIT'09. Fourth International Conference on (pp. 1469-1473). IEEE.

[2] Angelova, B., \& Zekiri, J. 2011. Measuring Customer Satisfaction with Service Quality Using American Customer Satisfaction Model (ACSI Model). International Journal of Academic Research in Business and Social Sciences, 1(3), 27.

[3] AISudairi, M. A. T. 2012. E-Service Quality Strategy: Achieving Customer Satisfaction in Online Banking.' Journal of Theoretical and Applied Information Technology 38.1.

[4] Nasri, Wadie. 2011. Factors influencing the adoption of Internet banking in Tunisia.' International Journal of Business and Management 6.8 (2011): p143.

[5] Wang, C., \& Wang, Z. 2006. The impact of Internet on service quality in the banking sector. Lulea University Master.

[6] Shanka, Mesay Sata. 2012. Bank Service Quality, Customer Satisfaction and Loyalty in Ethiopian Banking Sector. Journal of Business Administration and management Science Research 1.1 (2012): 001-009.

[7] Abbas Toloie-Eshlaghy and Sarah Ghafelehbashi. 2011. An Investigation and Ranking Public and Private Islamic Banks Using Dimension of Service Quality (SERVQUAL) Based on TOPSIS Fuzzy Technique. Applied Mathematical Sciences, Vol. 5, 2011, no. 61, 3031 - 3049.

[8] Parasuraman, A., Zeithaml, V. A., \& Malhotra, A. 2005.ES-QUAL a multiple-item scale for assessing electronic service quality. Journal of service research, 7(3), 213-233.

[9] Amoako, G. K. 2012. Improving Customer Service in the Banking Industry-Case of Ghana Commercial Bank (GCB)-Ghana. International Business Research, 5(4), p134.

[10] Kumbhar, V. 2011. Service quality perception and customers' satisfaction in Internet banking service: a case study of public and private sector banks. Published in: Cyber Literature: The International Online Journal , Vol. 2, No. 4 (10. December 2011): pp. 21-30.

[11] Ahmad, A. M. K., \& Al-Zu'bi, H. A. 2011. E-banking functionality and outcomes of customer satisfaction: an empirical investigation. International Journal of Marketing Studies, 3(1), p50.

[12] http://www.aba.com/Pages/default.aspx.

[13] Divya, S. and Padhmanabhan, V. 2008. A Study on Customer Perception Towards Internet Banking: Identifying Major Contributing Factors. The Journal of Nepalese Business Studies, Vol. V No. 1, December 2008, pp 101-111. 
[14] Jun, M., \& Cai, S. 2001. The key determinants of internet banking service quality: a content analysis. International Journal of Bank Marketing, 19(7), 276-291.

[15] Yasir Ali and Asif Niaz. 2010. The delicate balance of internet banking and bricks and mortar offices. Gotland University. Master Thesis in Business Administration.

[16] Joseph, M., McClure, C. and Joseph, B., 1999 'Service quality in banking sector: the impact of technology on service delivery', International Journal of Bank Marketing, Vol. 17, No. 4, pp.182-191.

[17] Hassan, M. T., Mukhtar, A., Ullah, R. K., Shafique, H., and Rehman, S. U., (2012), 'Customer Service Quality Perception of Internet Banking.' International Journal of Learning \& Development, 2(2),101-111.

[18] Slu, N. Y.M. \& Mou, J.C.W. 2003. A study of service quality in Internet banking, BRC Working papers may 2003, Hong Kong Baptist University.

[19] Safeena, R., \& Date, H. 2010. Customer perspectives on e-business value: Case study on Internet banking. Journal of Internet Banking and Commerce, 15(1), 1-13.

[20] Suzana Đukić and Velida Kijevčanin. 2012 Service Quality as Determinant of Customer satisfaction. FACTA UNIVERSITATIS Series: Economics and Organization Vol. 9, No 3, 2012, pp. $311-325$.

[21] Hossein Vazifedoosta, Mahmood Ansarb and Amir Yekezarec. 2013. How customer satisfaction changes behavior: A case study of banking industry. Management Science Letters 3 (2013) 1587-1592.

[22] Wahyuningsih. Tri \& Liestyana. Yuli. 2011. Quality Tools and Customer Satisfaction In Banking Sector International Journal of Business and Management Tomorrow, 1(2) 1-18.

[23] Molla,A., and Licker,P.S. 2001. E-commerce system success: An attempt to extend and respecify the Delone and Mclean Model of IS success Journal of Electronic commerce Research, vol.2,No.4.

[24] Agbor, Jenet Manyi. 2011.The relationship between customer satisfaction and service quality: a study of three service sectors in Umeå.' PhD diss., Umeå University.

[25] Grönroos, C. 2000.Service Management and Marketing: a customer Relationship Management Approach, 2ndEd. England: John Wiley \& Sons, Itd.

[26] J. Santos. (2003), 'E-service quality - a model of virtual service dimensions', Managing Service Quality, Vol. 13 No. 3, pp. 233-247.

[27] Hollis, C. 2006. Service quality evaluation in internal healthcare service chains. Queensland University of Technology. Thesis.

[28] Van Der Merwe, Samantha. 2010. The Impact of Electronic Service Quality Dimensions on Customer Satisfaction". Research proposal Magister in Business Management in the Faculty of Business and Economic Sciences of the Nelson Mandela Metropolitan University

[29] Paluch, S., \& Blut, M. 2013. Service Separation and Customer Satisfaction: Assessing the Service Separation/Customer Integration Paradox. Journal of Service Research.

[30] Collier, J.E. and Bienstock, C.C. 2006. Measuring service quality in e-retailing, Journal of Service Research, Vol. 8 No. 3, pp. 260-75.

[31] Fassnacht, M. and Koese, I. 2006. Quality of electronic services: Conceptualizing and testing a hierarchical model. Journal of Service Research, 9(1), 19-31.

[32] Alanezi, M. A., Kamil, A., \& Basri, S. 2010. A proposed instrument dimensions for measuring e-government service quality. International Journal of u-and e-Service, 3(4), 1-18.

[33] Li, H., \& Suomi, R. 2009. A proposed scale for measuring e-service quality. International Journal of u-and eService, Science and Technology, 2(1), 1-10.

[34] Kenova, V., \& Jonasson, P. 2006.'Quality online banking services '(Doctoral dissertation, Jönköping University).

[35] Khalil, A. 2011. Online Service Quality and Customer Satisfaction: A case Study of Bank Islam Malaysia Berhad. Munich Personal RePEc Archive, (30782), 1-24.

[36] Hamadi, C. 2010. The impact of quality of online banking on customer commitment. Communications of the IBIMA, 2010,1-8.

[37] Dabholkar, P.A.1996. Consumer evaluations of new technology-based self-service options: an investigation of alternative models of service quality. International Journal of Research in Marketing, 13, 29-51.

[38] Liu, C. and Arnett, K.P. 2000. Exploring the factors associated with website success in the context of electronic ecommerce. Information and Management, Vol.38, No.1, pp.23-34. 
[39] Sohn, C.S. 2000. Customer evaluation of Internet-based quality and intention to re-use internet-based services', Unpublished dissertation, Southern Illinois University, IL: Carbondale.

[40] Riel, A.C.R., Liljander, V. and Jurriens, P. 2001. Exploring consumer evaluations of e-services: a portal site', International Journal of Servicelndustry Management, Vol. 12 No. 4, pp. 359-77.

[41] Parasuraman, A., V.A. Zeithaml\& L.L. Berry. 1988. SERVQUAL: A multiple-item scale for measuring consumer perceptions of service quality'.Journal of Retailing, 64(1), 12-40.

[42] Zeithaml, V.A., A. Parasuramanand A. Malhotra. 2002. Service quality delivery through web sites: A critical review of extant knowledge', Journal of the Academy of Marketing Science, 30(4), 362 - 375.

[43] Madu, C.N and A.A. Madu. 2002. Dimensions of e-quality'. International Journal of Quality \& Reliability Management, 19(3), 246 - 258.

[44] Parasuraman, A., Zeithaml, Valerie A. \& Berry, Leonard L. 1991. Refinement and reassessment of the SERVQUAL scale,' Journal of Retailing, vol. 67(4), p. 420-50.

[45] Kim, M., Kim, JH. and Lennon, S.J. (2006). 'Online service attributes available on apparel retail websites: An E-S QUAL approach.' Managing Service Quality, 16(1), 51-77.

[46] McQuitty, S and Peterson,R. 2000. Selling home entertainment on the internet: an overview of a dynamic market place', Journal of Consumer Marketing, Vol.17, Nos.2/3, pp.233-248.

[47] Mols, N .P. 2000. The Internet and services marketing the case of Danish retail banking Internet Research. Electronic Networking Applications and Policy, 10(1), 7-18.

[48] Chien-Ta Bruce Ho, Wen-Chuan Lin . 2010. Measuring the service quality of Internet banking: scale development and validation, Emerald 22.

[49] Howcroft, B., Hamilton, R.\& Hewer P. 2002. Consumer attitude and the usage and adoption of home based banking in the United Kingdom. International Journal of Bank Marketing, 20 (3), 111-21.

[50] Karjaluoto, H., Mattila, M., and Pento, T. 2002. Factors underlying attitude formation towards online banking in Finland. International Journal of Bank Marketing, Vol. 20 No. 6, pp. 261-72.

[51] Pikkarainen, T., Pikkarainen, K., Karjaluoto, H., and Pahnila, S. 2004. Consumer acceptance of online banking:an extension of the technology acceptance model. Internet Research, 14, (3).

[52] Kolodinsky, J.M., J.M. Hogarth and M.A. Hilgert. 2004. The adoption of electronic banking technologies by US consumers. Int. J. Bank Market., 22: 238-259. DOI: 10.1108/02652320410542536.

[53] Lassar, W.M., Manolis, C. and Lassar, S.S. 2005. The Relationship between Consumer Innovativeness, Personal Characteristics, and Online Banking Adoption', International Journal of Bank Marketing, 23, 176199.

[54] Ndung'u, Christine Wanjiru. 2012. Internet banking service quality and customer satisfaction at Barclays bank of Kenya'. Digital Repository.

[55] Ranganathan, C, and S Ganapathy.2002.Key dimensions of business-to-consumer web sites. Information \& Management39, no. 6: 457-465.

[56] Kotler, P. and K. Keller. 2006. Marketing Management.12th Edn., Pearson Education Inc. ,New Jersey.

[57] Sabah Abdullah Al-Somali, Roya Gholami, Ben Clegg.2008. Internet Banking Acceptance in the Context of Developing Countries: An Extension of the Technology Acceptance Model' Third European Conference on Management of Technology (EuroMOT 2008). Nice, France. ISBN 0-9815817-1-4.

[58] Molapo, M. E., \& Mukwada, G. 2011. The Impact of Customer Retention Strategies in the South African Cellular Industry: The Case of the Eastern Free State.' International Journal of Business, Humanities and Technology, 1(2).

[59] Nupur, J. 2010. E-Banking and Customers' Satisfaction in Bangladesh: An Analysis. International Review of Business Research Papers. Vol. 6. September. pp. 145-156.

[60] Gupta, K. K. and Bansal, I. 2012. Development of an Instrument to Measure Internet Banking Service Quality in India", Researchers World, Vol. 3, No. 2(2), pp.11-25.

[61] Raza, Syed Ali and Jawaid, Syed Tehseen and Hassan, Ayesha. 2013. Internet Banking and Customer Satisfaction in Pakistan., International Journal of Economics and Financial.

[62] Hussien, M., I and Abd El Aziz, R. 2013. Investigating e-banking service quality in one of Egypt's banks: a stakeholder analysis", The TQM Journal, Vol. 25 No. 5, pp.557 - 576

[63] Latimore, D., Watson, I. and Maver, C. 2001. The Customer Speaks: 3,300 Internet Users Tell Us What They Want from Retail Financial Services, 28 May, available at URL: http://www.mainspring.com/research/document/view/12099, 1215,00,html. 
[64] El-Shazly, Alaa. , 2009. Efficiency measures for banking groups in Egypt. Egyptian Center for Economic Studies.

[65] Central Bank of Egypt" http://www.cbe.org.eg/Banks_Licensed_to_carry_out_E-Banking.htmlast access (January, 2012)

[66] www.mcit.gov.eg

[67] Metwally, E., Hatem, T., \& Flood, R. 2012. Leadership Actions Facilitating Successful Implementation Of ATMs And Internet Banking In Egyptian Private Sector Banking. Journal of Information Technology Management, 23(1), 62.

[68] Bhattarai, S., \& Yadav, S. R. 2009. AHP application in banking: unfolding utility in a situation of financial crisis. Retrieved January, 18, $2010 . \quad$ "Central Bank of Egypt" http://www.cbe.org.eg/Banks_Licensed_to_carry_out_E-Banking.htm.

[69] Kim, Song-Kyoo.2013. Analytic Hierarchy Process Expansion for Innovation Performance Measurement Framework." Journal of Engineering.

[70] Saaty, T. L. 2008. Decision making with the analytic hierarchy process. Int. J. Services Sciences, 1(1), 83.

[71] Saaty, T.L.1982.Decision Making for Leaders Lifetime Learning Publications. Wadsworth, Belmon t., 1982.

[72] Chow, C. C., \& Luk, P. 2005. A strategic service quality approach using analytic hierarchy process. Managing Service Quality, 15(3), 278-289.

[73] Gao, S., Zhang, Z., \& Cao, C. 2010. Calculating Weights Methods in Complete Matrices and Incomplete Matrices. Journal of Software, 5(3), 304-311.

[74] Vaidya, O.S. and Kumar, S. 2006. Analytic hierarchy process: an overview of applications. European Journal of Operational Research 169(1): 1-29.

[75] Feizizadeh, B., \& Blaschke, T. 2013. GIS-multicriteria decision analysis for landslide susceptibility mapping: comparing three methods for the Urmia lake basin. Iran. Natural Hazards, 65(3), 2105-2128.

[76] Syamsuddin, I., \& Hwang, J. 2010.The Use of AHP in Security Policy Decision Making: An Open Office Calc Application". JOURNAL OF SOFTWARE, VOL. 5, NO. 10, OCTOBER 2010.

[77] Saaty,1990.“The Analytic Hierarchy Process, RWS Publications, Pittsburgh, PA.

[78] Palcic, I., \& Lalic, B. 2009.Analytical hierarchy process as a tool for selecting and evaluating projects. International Journal of Simulation Modelling, 8(1), 16-26.

[79] Wind, Y. and Saaty, T.L. 1980. Marketing applications of the analytic hierarchy process ,Management Science, Vol. 26 No. 7, pp. 641-58.

[80] Wang, Y.M., Luo, Y. \& Hua, Z. 2008. On the extent analysis method for fuzzy AHP and its applications. European Journal of Operational Research, 186(2), 735-747.

[81] Sarukkali, M. 2013.Replicated Stratified Sampling for Sensitivity Analysis Doctoral Dissertations http://digitalcommons.uconn.edu/dissertations.

[82] Phan, K. and Daim, T. 2011 .Exploring technology acceptance for mobile services', Journal of Industrial Engineering and Management, 4(2): 339-360.

[83] Kabir, G. and Hasin, M. 2011. Evaluation of customer oriented success factors in mobile commerce using fuzzy AHP', Journal of Industrial Engineering and Management, 4(2): 361-386.

[84] Valeo, M. 2010. Using the Analytic Hierarchy Process to Improve the Rutgers Simple Bridge Security Checklist", Master thesis, Rutgers, The State University of New Jersey.

[85] Majumdar. A, P. K. Majumdar and B. Sarkar.2005. Determination of the Technological Value of Cotton Fiber: A Comparative Study of the Traditional and Multiple- Criteria Decision-Making Approaches. 'Autex Research Journal, Vol. 5 (2) 71-80.

[86] Hussein. K.M, A.A. Hassan and M.M. Kamal. 2010. The Multiplicative Analytic Hierarchy Process (MIAHP) as a Quality Criterion Determining the Technological Value of the Egyptian Cotton Varieties." Amer. J. of Plant Sci. 1(2010) 106-112.

[87] Jounio, C. 2013. Supplier Selection Based On AHP Method: Supplier from China for Suomen Koristetuonti. Helsinki Metropolia University of Applied Sciences Bachelor of Business Administration European Business AdministrationThesis

\section{Author' biography}

Miran Ismail Hussien is an Associate Lecturer at the Arab Academy for Science and Technology and Maritime Transport. She is a PhD candidate at Cardiff Metropolitan University, UK. She has been awarded her Master of 
Business Administration, AASTMT, in 2007. She has published a number of academic papers in International conferences and academic journals in the E-Commerce field.

Rasha Abd El Aziz is currently an Ass. Professor at the Arab Academy for Science and Technology, Egypt. She is a SAP Certified Business Associate. She has been awarded her PhD in 2009, the University of the West of England, Bristol, UK. She was awarded her MBA in 2002, AASTMT. She has published a book at LAP publishing, and has published extensively in academic journals and International conferences. She has supervised and is currently supervising a number of PhD and Master Theses both in UK and Egypt.

\section{Appendix AHP Questionnaire}

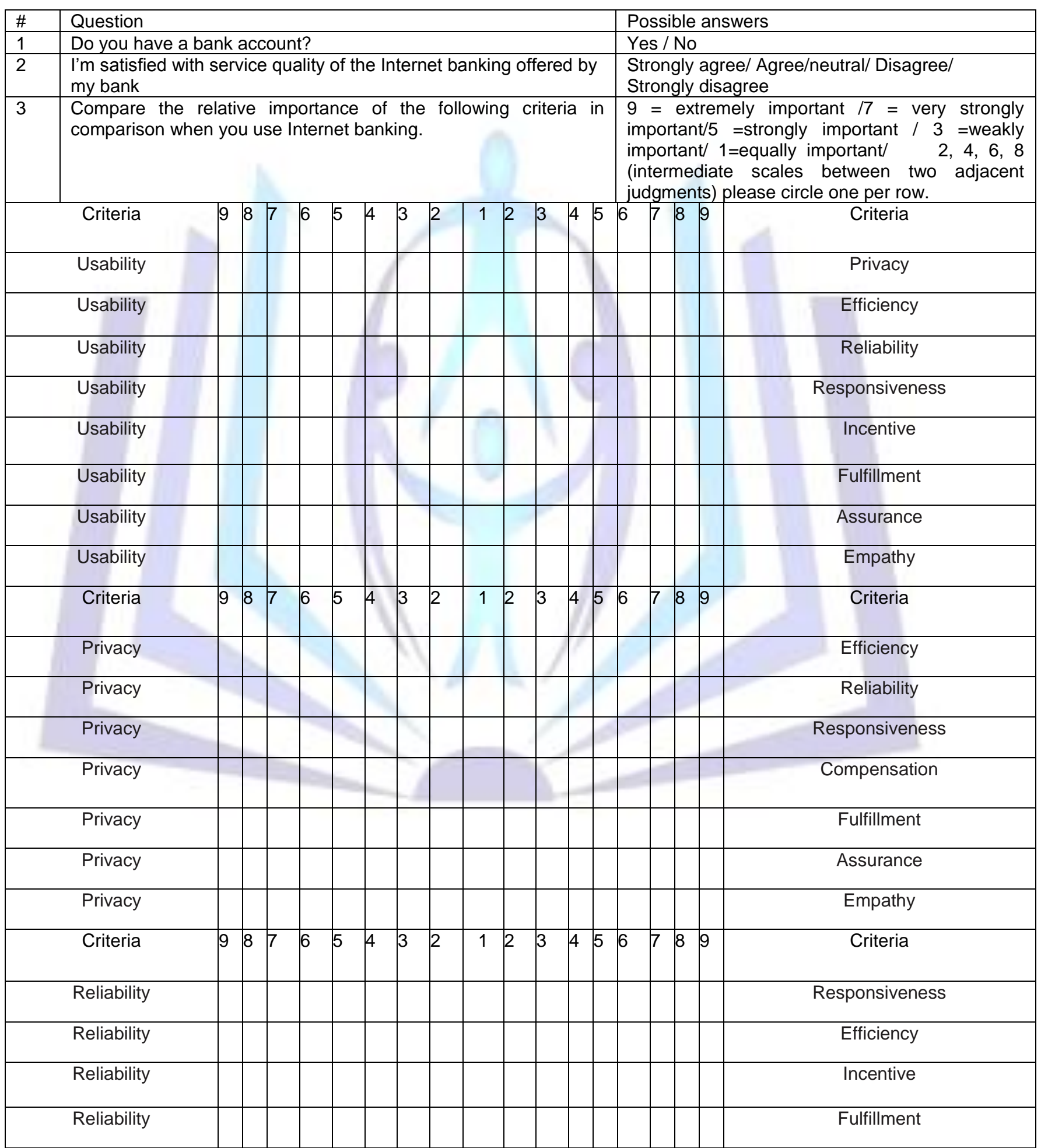




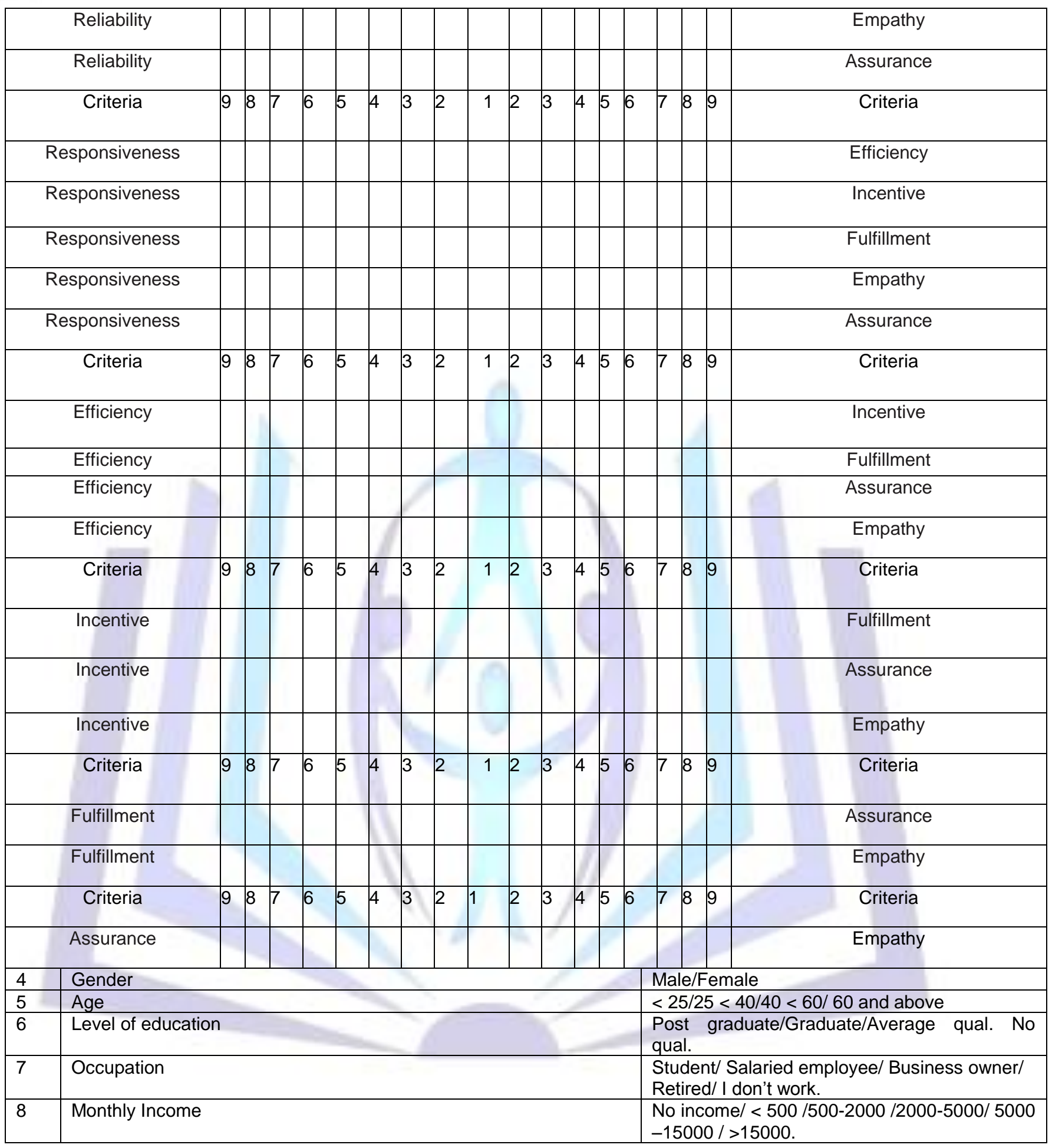

